\title{
LEAF MICRONUTRIENT CONCENTRATIONS AND POTENTIAL PHOTOSYNTHESIS IN Ochroma pyramidale ESTABLISHED IN A DEGRADED LAND
}

\author{
Ricardo A. MARENCO ${ }^{1 *}$, Gil VIEIRA ${ }^{1}$ and José F. de C. GONÇALVES ${ }^{1}$
}

ABSTRACT : In the Brazilian Amazon, large areas of abandoned lands may revert to secondary forest. In the process, pioneer tree species have an important role to restore productivity in old fields and improve environmental conditions. To determine potential photosynthesis $\left(\mathrm{A}_{\mathrm{pot}}\right)$, stomatal conductance $(\mathrm{g})$, transpiration $(E)$, and leaf micronutrient concentrations in Ochroma pyramidale (Cav. ex Lam.) Urban a study was carried out in the Brazilian Amazon $\left(01^{\circ} 51^{\prime} \mathrm{S} ; 60^{\circ} 04^{\prime} \mathrm{W}\right)$. Photosynthetic parameters were measured at increasing $\left[\mathrm{CO}_{2}\right]$, saturating light intensity ( $1 \mathrm{mmol}$ (photons) $\mathrm{m}^{-2} \mathrm{~s}^{-1}$ ), and ambient temperature. The rate of electron-transport $(J), \mathrm{A}_{\text {pot' }}$ and water-use efficiency (WUE) increased consistently at increasing internal $\mathrm{CO}_{2}$ concentration $\left(\mathrm{C}_{1}\right)$. Conversely, increasing $\left[\mathrm{CO}_{2}\right]$ decreased $\mathrm{g}_{\mathrm{s}}, E$, and photorespiration $\left(\mathrm{P}_{\mathrm{r}}\right.$. At the $\mathrm{CO}_{2}$-saturated region of the $\mathrm{CO}_{2}$ response curve $(1.1 \mathrm{mmol}$ $\left(\mathrm{CO}_{2}\right) \mathrm{mol}^{-1}($ air $\left.)\right), J$ was $120 \mu \mathrm{mol}(e) \mathrm{m}^{-2} \mathrm{~s}^{-1}$ and $\mathrm{A}_{\text {pot }}$ reached up to $24 \mu \mathrm{mol}\left(\mathrm{CO}_{2}\right) \mathrm{m}^{-2} \mathrm{~s}^{-1}$. Likewise, at saturating $\mathrm{C}_{\mathrm{i}}, \mathrm{g}_{\mathrm{s}}$ and $E$ were 30 and $1.4 \mathrm{mmol}(\mathrm{H} \mathrm{O}) \mathrm{m}^{-2} \mathrm{~s}^{-1}$, respectively, and $\mathrm{P}$ about $1.5 \mu \mathrm{mol}\left(\mathrm{CO}_{2}\right) \mathrm{m}^{-2} \mathrm{~s}^{-1}$. Foliar nutrients were $185,134,50$, and $10 \mu \mathrm{mol}$ (element) $\mathrm{m}^{\mathrm{r}}$ ${ }^{2}$ (leaf area) for $\mathrm{Fe}, \mathrm{Mn}, \mathrm{Zn}$, and $\mathrm{Cu}$, respectively. It was concluded that $\left[\mathrm{CO}_{2}\right]$ probably limits light saturated photosynthesis in this site. Furthermore, from a nutritional point of view, the low Fe to $\mathrm{Cu}$ ratio $(15: 1)$ may reflect nutritional imbalance in O. pyramidale at this site.

KEYWORDS: Balsa wood, electron-transport rate, reforestation, stomatal conductance, transpiration, water-use efficiency.

\section{CONCENTRAÇÃO DE MICRONUTRIENTES NAS FOLHAS E FOTOSSÍNTESE POTENCIAL EM Ochroma pyramidale ESTABELECIDO NUMA ÁREA DEGRADADA}

RESUMO : Extensas áreas abandonadas na Amazônia brasileira revertem para floresta secundária. Neste processo, as espécies pioneiras desempenham um papel importante na recuperação da produtividade de campos abandonados e na melhoria das condições ambientais. Para determinar a fotossíntese potencial $\left(\mathrm{A}_{\mathrm{pot}}\right)$, condutância estomática $\left(\mathrm{g}_{\mathrm{s}}\right)$, transpiração $(E)$, and a concentração de micronutrientes na folha em Ochroma pyramidale (Cav. ex Lam.) Urban um estudo foi realizado na Amazônia brasileira (01 51' LS; $60^{\circ} 04^{\prime} \mathrm{LO}$ ). Os parâmetros

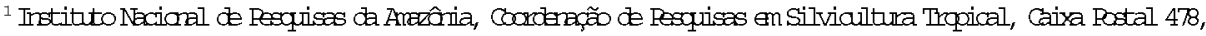
69011-970 Maneus, PM. *Corresponcing athor E-mail: marencoxinpa.gov.br
} 
fotossintéticos foram medidos a níveis crescentes de $\mathrm{CO}_{2}$ sob luz saturante (1 mmol (fótons) $\left.\mathrm{m}^{-2} \mathrm{~s}^{-1}\right)$ e temperatura ambiente. A taxa de transporte de elétrons $(J), \mathrm{A}_{\mathrm{pot}}$ e a eficiência no uso d'água (WUE) aumentaram consistentemente com aumentos na concentração interna de $\mathrm{CO}_{2}(\mathrm{C})$. Ao contrário, aumentos na $\left[\mathrm{CO}_{2}\right]$ diminuíram $\mathrm{g}_{\mathrm{s}}, E$ e a fotorrespiração $(\mathrm{P})$. $\mathrm{Na}$

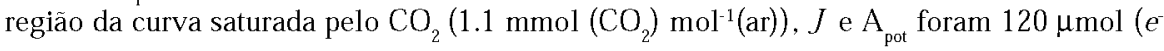
$\mathrm{m}^{-2} \mathrm{~s}^{-1}$ e $24 \mu \mathrm{mol}\left(\mathrm{CO}_{2}\right) \mathrm{m}^{-2} \mathrm{~s}^{-1}$, respectivamente. Paralelamente, sob $\mathrm{C}_{\mathrm{i}}$ saturante, $\mathrm{g}_{\mathrm{s}}$ and $E$ foram 30 e $1.4 \mathrm{mmol}\left(\mathrm{H} \mathrm{O}_{2} \mathrm{O}\right) \mathrm{m}^{-2} \mathrm{~s}^{-1}$, respectivamente, enquanto que $\mathrm{P}_{\mathrm{r}}$ foi em torno de 1.5 $\mu \mathrm{mol}\left(\mathrm{CO}_{2}\right) \mathrm{m}^{-2} \mathrm{~s}^{-1}$. Os teores de micronutrientes da folha foram $185,134,50$ e $10 \mu \mathrm{mol}$ (elemento) $\mathrm{m}^{-2}$ (área foliar) para $\mathrm{Fe}, \mathrm{Mn}, \mathrm{Zn}$ e $\mathrm{Cu}$, respectivamente. Foi concluído que a $\left[\mathrm{CO}_{2}\right]$ provavelmente limita a fotossíntese sob luz saturante neste sítio. Além disso, do ponto de vista nutricional, a baixa relação ferro:cobre, de 15 para 1 , pode indicar um debalanço nutricional em $O$. pyramidale neste sítio.

PALAVRAS-CHAVE: condutância estomática, eficiência no uso d'água, pau-de-balsa, eflorestamento, taxa de transporte de elétrons, transpiraçāo.

\section{INTRODUCTION}

Many factors, such as availability of water, carbon dioxide, light, and nutrients affect photosynthesis in several ways. Increases in $\mathrm{CO}_{2}$ concentrations enhance photosynthetic rates in $\mathrm{C}_{3}$ plant species. Whereas, compared with $\mathrm{C}_{3}$ plants, $\mathrm{C}_{4}$ plants, which are able to concentrate $\mathrm{CO}_{2}$, show higher photosynthetic rates and are better adapted to tropical regions exposed to higher temperatures and soils with lower water availability. In Brazilian Amazonia, large areas of abandoned lands may revert to secondary forests (Houghton et al., 2000). In this process pioneer tree species have an important role in restoring productivity in old fields and improve environmental conditions. Although pioneer tree species are greatly important to restore soil fertility of degraded lands, little is known about the physiology of pioneer trees in these degraded habitats.

In addition to $\mathrm{CO}_{2}$, light and temperature, mineral nutrition affects photosynthesis in several ways. Micronutrients such as iron, manganese, and copper are constituents of proteins involved in electron transfers. For example, $\mathrm{Cu}$ is a component of plastocyanin and $\mathrm{Fe}$ is a constituent of cytochromes and required for chlorophyll biosynthesis (Beale, 1999), whereas $\mathrm{Mn}$ plays a key role in photosynthetic $\mathrm{O}_{2}$ evolution. $\mathrm{Zn}$, on the other hand, is required as a structural component of several enzymes (e.g., carbonic anhydrase, super oxide dismutase) and for ribosomes synthesis and activity (Marschner, 1995).

Ochroma pyramidale is a pioneer neotropical tree that grows under moist and warm conditions on disturbed lands or as a colonizer of large gaps in the secondary rain forest (Whitmore \& Wooi-Khoon, 1983; Kammesheidt, 2000). Its high performance in large gaps has been attributed to a high investment in leaf biomass, which results in a high leaf area ratio (Dalling et al., 1999). Its growth is faster in fertile soils when mean temperature ranges from 25 to $30^{\circ} \mathrm{C}$ and 
average annual rainfall is from 1500 to about 2000 mm (Francis, 1991; Butterfield, 1996). Besides its fast growth, direct solar radiation (full sun) apparently does not depress photochemical efficiency of Ochroma seedlings grown with adequate availability of water and nutrients (Castro et al., 1995). Acclimation of Ochroma and other pioneer species to high-light stress under strong radiation has been attributed at least in part to their capability to increase the levels of photoprotective pigments (e.g., $b$ carotene) and the chlorophyll $a / b$ ratio (Krause et al., 2001). Ochroma may exhibit high photosynthetic rates under ambient $\mathrm{CO}_{2}$ concentrations (Oberbauer \& Strain, 1984; Dalling et al., 1999). However, in degraded landscapes, low availability of nitrogen and magnesium appears to be factors that limit carbon gain in this species (Marenco et al., 2001 a). The fast growth of Ochroma saplings makes this species potentially useful in reforestation projects on sites with proper management, but other species should be considered for reforestation over large regions on poor soils where plantation maintenance is scarce (Butterfield, 1996). When Ochroma is planted in mixtures with late successional, slower-growing species, it may provide shading for the seedlings of the slower-growing species and improve soil fertility by nutrient cycling.

In this study we hypothesized that potential photosynthesis $\left(\mathrm{A}_{\text {pot }}\right.$ ) (i.e., the lightsaturated photosynthesis at $\mathrm{CO}_{2}$-saturated conditions) and other photosynthetic parameters, as well as the foliar micronutrient content of pioneer tree species are lower when grown in degraded lands than under controlled conditions or in mature forests. Therefore, we determined leaf gas exchange parameters and leaf micronutrient concentrations in $O$. pyramidale grown in a degraded landscape and compared these values with published data (e.g., Oberbauer \& Strain, 1984; Neves et al., 1999). We also compared $A_{\text {pot }}$ with photosynthetic rates of $\mathrm{C}_{4}$ plants, a group of plants with $\mathrm{CO}_{2}$-concentrating mechanisms. In the absence of gas exchange data from $\mathrm{C}_{4}$ tree grown in the open, we use $C_{4}$ data from herbaceous dicots reported elsewhere (Grodzinski et al., 1998).

\section{MATERIALS AND METHODS}

Data were collected from Ochroma pyramidale (Cav. ex Lam.) Urban, Bombacaceae, (hereafter, Ochroma) grown on experimental plots located near Presidente Figueiredo (01 $51^{\prime}$ $\mathrm{S} ; 60^{\circ} 04^{\prime} \mathrm{W}$ ) in the Brazilian Amazon. Ochroma was chosen because it is one of the faster-growing species in the neotropical region under favorable conditions (Butterfield, 1996).

The region has a humid tropical climate and receives an annual precipitation of about $2200 \mathrm{~mm}$, with a wet season from October through June. Mean temperature is around 27 ${ }^{\circ} \mathrm{C}$. Net assimilation rate $(A)$, stomatal conductance to water vapor $(\mathrm{g})$, transpiration $(E)$, and leaf dark respiration $\left(\mathrm{R}_{\mathrm{d}}\right)$ were measured using an portable photosynthesis system with onboard LED light source and dioxide mixer to control $\mathrm{CO}_{2}$ partial pressure (LI-6400, Li-Cor, Lincoln, Neb., USA). Data were collected from September 2000 to March 2001 on fully expanded leaves of similar age and appearance.

Four one-year-old plants were randomly selected for measurements from a population of around 100 saplings. Gas exchange parameters were measured on fully expanded leaves (two leaves per plant) between 0900 and $1500 \mathrm{~h}$. Measurements were taken only in open sky days. Thus, when measurements were interrupted due to rainy conditions, a new set 
of data was taken again another day, in the same plant.

Individual leaves were treated as sub samples. $\mathrm{CO}_{2}$ response curves were determined for atmospheric $\mathrm{CO}_{2}$ concentration $\left(C_{a}\right)$ between 15 and $2000 \mu \mathrm{mol} \mathrm{mol}^{-1}$. During measurements, light intensity was maintained at $1 \mathrm{mmol}$ (photons) $\mathrm{m}^{-2} \mathrm{~s}^{-1}$ within the leaf chamber. Electron-transport rate $(J)$ was determined according to Farquhard \& Von Caemmerer (1982) as:

$$
J=4\left(\mathrm{~V}_{\mathrm{c}}+\mathrm{V}_{\mathrm{o}}\right) \text {, }
$$

where $V_{c}$ and $V$ are the rate of carboxylation and oxygenation, respectively. $\mathrm{V}_{\mathrm{c}}$ is given by:

$$
\mathrm{V}_{\mathrm{c}}=A+0.5 \mathrm{~V}_{\mathrm{o}}+\mathrm{R}_{\mathrm{d}} .
$$

The oxygenation rate $\left(V_{0}\right)$ can be calculated as: $V_{0}=\left(A+R_{d}\right) /(1 / \Phi-0.5)$, being $\Phi$ described by the following equation as (Lambers et al. 1998):

$$
\Phi=2(3.7+0.188(T-25)+0.0036
$$
$\left.(T-25)^{2}\right) / \mathrm{P}_{\mathrm{i}}$,

where $T$ is temperature $\left({ }^{\circ} \mathrm{C}\right)$ and $\mathrm{P}_{\mathrm{i}}$ is the $\mathrm{CO}_{2}$ partial pressure $\left(\mathrm{P}_{\mathrm{a}}\right)$. Because $\mathrm{V}_{\mathrm{o}}$ is twice the rate of photorespiration, $\mathrm{P}_{\mathrm{r}}$ was computed as: $\mathrm{P}_{\mathrm{r}}=\mathrm{V}_{\mathrm{o}} / 2$. Net photosynthetic rate $(A)$ data were fit using non-linear least squared regression, according to the model proposed by Herrick \& Tomas (2001) as:

$$
A=\mathrm{A}_{\text {pot }}^{\prime}\left[1-\left(1-\mathrm{y}_{0} / \mathrm{A}_{\text {pot }}^{\prime}\right)^{(1-\mathrm{C} / \Gamma)}\right.
$$

where $\mathrm{y}_{0}$ is the $\mathrm{y}$-intercept, $\Gamma$ is the $\mathrm{CO}_{2}$-compensation point, and $\mathrm{A}^{\prime}$ pot is the computed $\mathrm{A}_{\text {pot }}$ (i.e., the actual light-saturated photosynthesis at saturating $\mathrm{C}_{\mathrm{i}}$ ).

Micronutrients (Fe, Zn, Mn, and $\mathrm{Cu}$ ) were determined by atomic absorption spectrophotometry (Perkin Elmer 1100B, Überlingen, Germany) as described by Miyazawa et al. (1999). The ratio between $\mathrm{A}_{\max }$ (i.e., net assimilation at saturating light intensity and ambient $\mathrm{CO}_{2}$ ) and micronutrient concentration was also calculated.

\section{RESULTS}

\section{Gas exchange and electron-transport}

At ambient $\mathrm{C}_{\mathrm{a}}\left(\mathrm{C}_{\mathrm{i}}=255 \mu \mathrm{mol}\left(\mathrm{CO}_{2}\right) \mathrm{mol}^{-}\right.$ ${ }^{1}$ (air)), light-saturated photosynthesis $\left(\mathrm{A}_{\max }\right)$ was $9.3 \mu \mathrm{mol}\left(\mathrm{CO}_{2}\right) \mathrm{m}^{-2} \mathrm{~s}^{-1}$, whereas at saturating $\mathrm{C}_{\mathrm{a}}\left(\right.$ i.e., $\mathrm{C}_{\mathrm{i}}=1100 \mu \mathrm{mol}(\mathrm{CO}) \mathrm{mol}^{-}$ ${ }^{1}($ air $\left.)\right), A_{\text {pot }}$ was $24 \mu \mathrm{mol}\left(\mathrm{CO}_{2}\right) \mathrm{m}^{-2} \mathrm{~s}^{-1}$ (Figure 1). Electron-transport rates $(J)$ increased from 81 to $120 \mu \mathrm{mol}\left(e^{-}\right) \mathrm{m}^{-2} \mathrm{~s}^{-1}$, at increasing $\left[\mathrm{CO}_{2}\right]$ above ambient $C_{a}$ (Figure 1 ). The $C_{i} / C_{a}$ ratios were 0.657 and 0.55 at ambient and saturating $C_{a}$, respectively.

$E$ and $\mathrm{g}_{\mathrm{s}}$ decreased at elevated $\mathrm{C}_{\mathrm{i}} . E$ dropped from 2.7 to $1.49 \mathrm{mmol}\left(\mathrm{H}_{2} \mathrm{O}\right) \mathrm{m}^{-2} \mathrm{~s}^{-1}$ and $\mathrm{g}_{\mathrm{s}}$ from 170 to $35 \mathrm{mmol}\left(\mathrm{H}_{2} \mathrm{O}\right) \mathrm{m}^{-2} \mathrm{~s}^{-1}$ at ambient and saturating $\mathrm{CO}_{2}$ concentration, respectively (Figure 2 ). As a result of reduction in water loss and increases in $A$ at increasing $\mathrm{C}_{\mathrm{i}}$, WUE was much lower at ambient $\mathrm{C}_{\mathrm{a}}$ than at elevated $\mathrm{CO}_{2}$ concentration (i.e., 5.43 versus $15.48 \mathrm{mmol}\left(\mathrm{CO}_{2}\right) \mathrm{mol}^{-1}\left(\mathrm{H}_{2} \mathrm{O}\right)$. The $\mathrm{CO}_{2}$ compensation point $(\Gamma)$ was estimated as 59.2 $\mu \mathrm{mol}\left(\mathrm{CO}_{2}\right) \mathrm{mol}^{-1}$ (air) (Figure 1).

\section{Leaf micronutrients}

Leaf micronutrient concentrations on a leaf area basis were $185,134,50$, and $10 \mu \mathrm{mol}$ (element) $\mathrm{m}^{-2}$ for $\mathrm{Fe}, \mathrm{Mn}, \mathrm{Zn}$, and $\mathrm{Cu}$, respectively. The $\mathrm{A}_{\max }$ to micronutrient ratio ranged from 50 to $883 \mathrm{mmol}\left(\mathrm{CO}_{2}\right) \mathrm{mol}^{-}$ ${ }^{1}$ (element) $\mathrm{s}^{-1}$. Highest and lowest $\mathrm{A}_{\max }$ :nutrient ratios involved $\mathrm{Cu}$ and $\mathrm{Fe}$, respectively (Table 1). The Fe to $\mathrm{Cu}$ ratio was rather low (15:1), which may indicate nutritional imbalance in this species. 


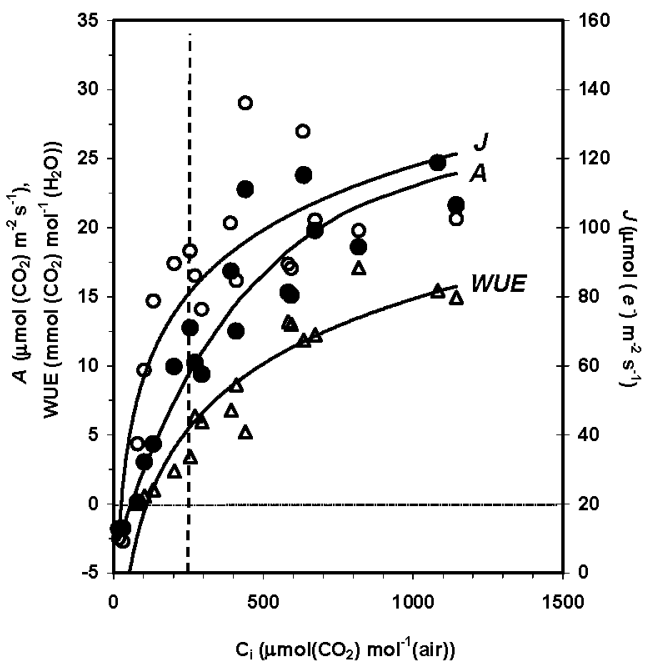

Figure 1. Electron-transport rates (J), net photosynthesis (A), and water-use efficiency (WUE) in Ochroma pyramidale grown in experimental plots near Presidente Figueiredo (AM) as a function of the internal $\mathrm{CO}_{2}$ concentration $\left(C_{i}\right)$. Vertical dashed line shows $C_{i}$ at ambient $C_{2}$ concentration (i.e., $C_{i}=254$ $\left.\mu \mathrm{mol} \mathrm{mol}^{-1} ; \mathrm{C}_{1} / \mathrm{C}_{a}=0.67\right)$. Symbols: o, electron-transport rates; $\bullet$, net photosynthesis; $\Delta$, wateruse efficiency. $J(0)=-66.72+26.71$ In $C_{i}, R^{2}=0.79 ; A(\bullet)=26\left[1-(1+3.83 / 26)^{\left(1-C_{i}(59.2)\right.}, R^{2}=0.94\right.$; $\operatorname{WUE}(\Delta)=-32.02+6.78 \operatorname{In} \mathrm{C}_{i}, \mathrm{R}^{2}=0.89$. The $\mathrm{CO}_{2}$ compensation point $(I)$ was $59.2 \mu \mathrm{mol}\left(\mathrm{CO}_{2}\right)$ mol ${ }^{1}$ (air); In, natural logarithm. Each point is the mean of four plants and two leaves per plant.

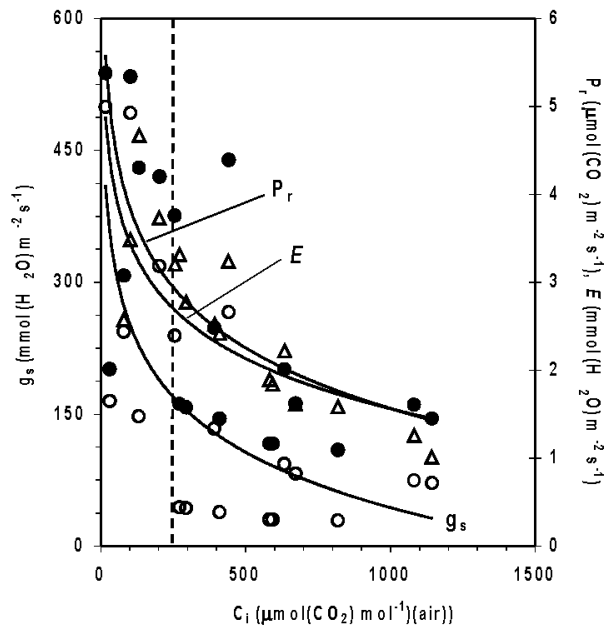

Figure 2. Stomatal conductance $\left(\mathrm{g}_{\mathrm{s}}\right)$, transpiration $(E)$, and photorespiration $\left(\mathrm{P}_{\mathrm{r}}\right)$ in Ochroma pyramidale grown in experimental plots near Presidente Figueiredo (AM) as a function of the internal $\mathrm{CO}_{2}$ concentration $\left(C_{i}\right)$. Vertical dashed line shows $C_{1}$ at ambient $\mathrm{CO}_{2}$ concentration (i.e., $\mathrm{C}_{i}=254$ $\left.\mu \mathrm{mol}\left(\mathrm{CO}_{2}\right) \mathrm{mol}^{-1}(\mathrm{air}) ; \mathrm{C} / \mathrm{C}_{\mathrm{a}}=0.67\right)$. Symbols: o, stomatal conductance; $\bullet$, transpiration; $\Delta$, photorespiration. $\mathrm{g}_{s}(\mathrm{o})=670.9-90.8 \ln \mathrm{C}_{i}, \mathrm{R}^{2}=0.49 ; E(\bullet)=7.23-0.82 \ln \mathrm{C}_{i}, \mathrm{R}^{2}=0.41 ; \mathrm{P}_{\mathrm{r}}(\Delta)$ $=8.43-0.99 \ln C_{i}, R^{2}=0.64 ;$ In, natural logarithm. Each point is the mean of four plants and two leaves per plant. 
Table 1. Leaf micronutrient concentrations and $A_{\max }$ to nutrient ratio in Ochroma pyramidale grown in experimental plots near Presidente Figueiredo, AM. Each value is the mean of four plants $( \pm S . D)$.

\begin{tabular}{l|r|c|c|c}
\hline Parameter & Mean \pm S.D & Mean \pm S.D & $\begin{array}{c}\text { Critical } \\
\text { deficiency levels }\end{array}$ & $\begin{array}{c}\mathrm{A}_{\max } \text { to nutrient } \\
\text { ratio }^{2}\end{array}$ \\
\hline \multirow{3}{*}{ Iron } & \multicolumn{1}{|c|}{$\left(\mathrm{mg} \mathrm{kg}^{-1} \mathrm{DM}\right)$} & $\left(\mu \mathrm{mol} \mathrm{m}{ }^{-2}\right.$ leaf area $)$ & $\left(\mathrm{mg} \mathrm{kg}^{-1} \mathrm{DM}\right)$ & $\left(\mathrm{mmol}^{\left.\left(\mathrm{CO}_{2}\right) \mathrm{mol}^{-1} \mathrm{~s}^{-1}\right)}\right.$ \\
\cline { 2 - 5 } Zinc & $100.5 \pm 19.1$ & $185.1 \pm 3.53$ & 50 to 150 & 50.2 \\
Manganese & $32.0 \pm 3.6$ & $50.3 \pm 5.7$ & 15 to 20 & 184.7 \\
Copper & $71.5 \pm 5.5$ & $133.9 \pm 10.3$ & 10 to 20 & 69.5 \\
\hline
\end{tabular}

${ }^{1-L e a f}$ critical deficiency content according to Marschner (1995)

${ }^{2}$ For an $A_{\max }$ of $9.3 \mu \mathrm{mol}\left(\mathrm{CO}_{2}\right) \mathrm{mol}^{-2} \mathrm{~s}^{-1}$

\section{DISCUSSION}

\section{Gas exchange and electron-transport}

Mean $\mathrm{A}_{\text {max }}$ was much lower than previously reported for Ochroma (i.e., 9.3 versus $27 \mu \mathrm{mol}(\mathrm{CO}) \mathrm{m}^{-2} \mathrm{~s}^{-1}$ ) (Figure 1 , Oberbauer \& Strain, 1984). This difference was attributed to the fact that Oberbauer \& Strain collected their data from plants grown at near-optimal conditions. Thus, compared with Ochroma grown in controlled conditions, our results suggest that in this degraded landscape, environmental factors such as availability of nutrients in the soil may limit photosynthesis in this species. However, our $A_{\max }$ values were comparable to values obtained for other pioneer tree species grown under natural environments (Zotz \& Winter, 1994; Ishida et al., 1999).

On the other hand, $A_{\text {pot }}$ reported in this study is within the range observed for some $\mathrm{C}_{4}$ dicot species such as Amaranthus retroflexus and Gomphrena globosa (Grodzinski et al., 1998). One could suggest that expected increases in atmospheric $\left[\mathrm{CO}_{2}\right]$ could enhance photosynthetic rates of Ochroma in the future. However, we must bear in mind that leaf response to short-term exposure to elevated $\left[\mathrm{CO}_{2}\right]$ should not be extrapolated to whole-plant response over the long-term because several factors may modulate plant response to permanent exposure to elevated atmospheric $\left[\mathrm{CO}_{2}\right]$. Compared with ambient $\left[\mathrm{CO}_{2}\right]$, short-term exposure to elevated $\left[\mathrm{CO}_{2}\right]$ decreased $\mathrm{P}_{\mathrm{r}}$ by $50 \%$, from 2.9 to $1.46 \mu \mathrm{mol}\left(\mathrm{CO}_{2}\right) \mathrm{m}^{-2} \mathrm{~s}^{-1}$ (Figure 1).

The $\mathrm{CO}_{2}$ compensation point found in O. pyramidale (i.e., $59 \mu \mathrm{mol}\left(\mathrm{CO}_{2}\right) \mathrm{mol}^{-1}$, Figure 1) was lower than previously reported for Swietenia macrophylla, another lightdemanding species (Marenco et al., 2001 b), due to the lower respiration rates of Ochroma. Our $\mathrm{C}_{\mathrm{i}} / \mathrm{C}_{\mathrm{a}}$ values were lower than those previously reported for other rainforest species (Carswell et al., 2000). Differences in the $C_{i} / C_{a}$ ratio among plant species have been attributed at least in part to variation in stomatal conductance to $\mathrm{CO}_{2}$ (Ehleringer \& Cerling,1995).

Transpiration rates and $\mathrm{g}_{s}$ decreased consistently at increasing $\left[\mathrm{CO}_{2}\right]$ confirming that at elevated $\mathrm{CO}_{2}$ supply water loss may be reduced significantly. Thus, WUE was near three times higher at elevated $\left[\mathrm{CO}_{2}\right]$ than at 
ambient $\mathrm{CO}_{2}$ concentration (i.e., 5.43 versus

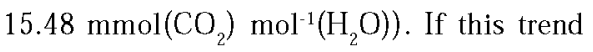
is maintained at the whole plant level, we may speculate that as atmospheric $\left[\mathrm{CO}_{2}\right]$ increases Ochroma could colonize areas with rainfall lower than $1500 \mathrm{~mm}$ year $^{-1}$ or areas with a longer drought period. Our maximum $J$ values were similar to those previously observed in the upper canopy of Inga sp. in an undisturbed Amazonian forest (Carswell et al., 2000 ), indicating that the photosynthetic system of Ochroma was apparently little or not affected by the harsh environmental conditions of this degraded landscape.

\section{Leaf micronutrients}

Little is known about the mineral composition of Ochroma. Therefore, in the absence of data from this species, we compared our results with those obtained from other tropical trees. Iron content of Ochroma was almost twice as high as those previously reported for other tropical trees (e.g., Ceiba pentandra, Virola surinamensis), grown on low fertility soils (Neves et al., 1999). However, these differences may not necessarily imply shortage of this element in the soil because variations in Fe content among species appear to be common for this element. In Burkina Faso, for example, leaf Fe content ranged from values as low as $14 \mathrm{mg} \mathrm{kg}^{-1}$ up to $155 \mathrm{mg} \mathrm{kg} \mathrm{kg}^{-1}$ (Glew et al., 1997).

Mn leaf content in Ochroma was within the range reported for $C$. pentandra and $V$. surinamensis by Neves et al. (1999). Zn leaf concentration, on the other hand, was higher in Ochroma than in those species studied by Neves et al. (1999). Compared with other tropical species, $\mathrm{Mn}, \mathrm{Zn}$, and $\mathrm{Cu}$ concentrations are within the range reported by Glew et al. (1997). Taking into account the critical deficiency levels established for higher plants (Marschner, 1995), we may conclude that in terms of mineral nutrition, contents of $\mathrm{Fe}, \mathrm{Cu}$, and $\mathrm{Zn}$ were within the adequate range. On the other hand, $\mathrm{Mn}$ concentrations were slightly high, but lower than levels considered excessive for several plant species (i.e., above $200 \mathrm{mg} \mathrm{kg}^{-1}$ ) (Marschner 1995). Furthermore, from a nutritional point of view, the low $\mathrm{Fe}$ to $\mathrm{Cu}$ ratio (15:1) may reflect nutritional imbalance in $O$. pyramidale at this site. None of micronutrients examined was apparently insufficient or excessive for limiting the growth of Ochroma in this site, in which high growth rate has been observed (Barbosa et al., 2000).

\section{CONCLUSIONS}

In this degraded landscape, a rather low $\mathrm{A}_{\max }$ was found in Ochroma $\left(9.3 \mu \mathrm{mol}\left(\mathrm{CO}_{2}\right)\right.$ $\left.\mathrm{m}^{-2} \mathrm{~s}^{-1}\right)$. Mean $A_{\text {pot }}$ reported in this study is within the range observed for some $C_{4}$ dicot species suggesting that under optimal environmental conditions photosynthetic rates of Ochroma may increase significantly. Transpiration rates and $\mathrm{g}_{s}$ lowered drastically at elevated $\left[\mathrm{CO}_{2}\right]$ confirming that at elevated $\mathrm{CO}_{2}$ concentrations water loss may be significantly reduced, and as a result WUE may be increased. Considering the critical deficiency levels for most higher plants, we may conclude that the contents of $\mathrm{Fe}, \mathrm{Cu}$, and $\mathrm{Zn}$ were apparently adequate, whereas the content Mn was slightly high. Finally, none of the micronutrients examined was apparently insufficient or excessive for limiting the growth of Ochroma in this site, although the low Fe to $\mathrm{Cu}$ ratio $(15: 1)$ may reflect nutritional imbalance in this species. 


\section{ACKNOWLEDGMENTS}

We thank Dr. A. P. Barbosa for assistance. The study was supported by the Brazilian Ministry of Science and Technology and the Brazilian Amazon Forest Research Project - Japanese International Cooperation Agency for financial support (Phase II project $\mathrm{n}^{\circ}$ : 309-1064-E-1)

\section{LITERATURE CITED}

Barbosa, A.P.; Campos, M.A.A.; Sampaio, P.T.B.; Nakamura, S.; Gonçalves, C.Q.B. 2000. O crescimento de espécies florestais pioneiras na recuperação de áreas degradadas pela agricultura. In: Ferraz, I.D.K.; Sales, P.C.; Campos, M.A.A.; Sampaio, P.T.B.; Nakamura, S (Eds). Estudos para manejo florestal e recuperação de áreas degradadas: Resumos do Workshop intermediário do Projeto Jacaranda - Fase II. Manaus, Instituto Nacional de Pesquisas da Amazônia, Manaus, AM. p. 42.

Beale, S.I. 1999. Enzymes of chlorophyll biosynthesis. Photosyn. Res., 60:43-73.

Butterfield, R.P. 1996. Early species selection for tropical reforestation: a consideration of stability. For. Ecol. Manage., 81:161-168.

Carswell, F.E., Meir, P.; Wandelli, E.V.; Bonates, L.C.M.; Kruijt, B. ; Barbosa, E.M. ; Nobre, A.D. ; Grace, J. ; Jarvis. P.G. 2000. Photosynthetic capacity in a central Amazonian rain forest. Tree Physiol. 20:179-186.

Castro, Y.; Fetcher, N.; Fernández, D.S. 1995. Chronic photoinhibition in seedlings of tropical trees. Physiol. Plant., 94:560-565.

Dalling, J.W.; Lovelock, C.E.; Hubbell, S.P. 1999. Growth responses of seedlings of two neotropical pioneer species to simulated forest gap environments. J. Trop. Ecol., 15:827-839.

Ehleringer, J.R.; Cerling, T.E. 1995. Atmospheric $\mathrm{CO}_{2}$ and the ratio of intercellular to ambient $\mathrm{CO}_{2}$ concentrations in plants. Tree Physiol., 15:105-111.

Farquhar, G.D.; von Caemmerer, S. 1982. Modelling of photosynthetic response to environmental conditions. In: Lange, O.L.; Nobel, P.S.; Osmond, C.B.; Ziegler, H. (Eds). Encyclopedia of plant physiology, New Series. Vol. 12B. Springer-Verlag, Berlin. p. 549-587.

Francis, J.K. 1991. Ochroma pyramidale Cav. Balsa - Bombacaceae. SO. Institute of Tropical Forestry, USDA, SM-41. Río Piedras. PR. 6p.

Glew, R.H.; VanderJagt, D.J.; Lockett, C.; Grivetti, L.E.; Smith, G.C.; Pastuszyn, A.; Millson, M. 1997. Amino acid, fatty acid, and mineral composition of 24 indigenous plants of Burkina Faso. J. Food Comp. Anal., 10:205-217.

Grodzinski, B.; Jiao, J.; Leonardos, E.D. 1998. Estimating photosynthesis and concurrent export rates in $\mathrm{C}_{3}$ and $\mathrm{C}_{4}$ species at ambient and elevated $\mathrm{CO}_{2}$. Plant Physiol., 117:207217.

Herrick, J.D.; Thomas, R.B. 2001. No photosynthetic down-regulation in sweetgum trees (Liquidambar styraciflua L.) after three years of $\mathrm{CO}_{2}$ enrichment at 
the Duke Forest FACE experiment. Plant Cell Environ., 24:53-64.

Houghton, R.A.; Skole, D.L.; Nobre, C.A.; Hackler, J.L.; Lawrence, K.T.; Chomentowski, W.H. 2000. Annual fluxes of carbon from deforestation and regrowth in the Brazilian amazon. Nature, 403:301 304.

Ishida, A.; Toma, T.; Marjenah. 1999. Limitation of leaf carbon gain by stomatal and photochemical processes in the top canopy of Macaranga conifera, a tropical pioneer tree. Tree Physiol., 19:467-473.

Kammesheidt, L. 2000. Some autoecological characteristics of early to late successional tree species in Venezuela. Acta Oecol., 21:37-48.

Krause, G.H.; Koroleva, O.Y.; Dalling, J.W.; Winter K. 2001. Acclimation of tropical tree seedlings to excessive light in simulated tree-fall gaps. Plant Cell Envirron., 24:1345-1352.

Lambers, H.; Chapin III, F.S.; Pons, T.L.1998 Plant physiological ecology. SpringerVerlag, New York. Berlin, Heidelberg. 540p.

Marenco, R.A.; Gonçalves, J.F.C.; Vieira, G. 2001a. Photosynthesis and leaf nutrient contents in Ochroma pyramidale (Bombacaceae). Photosynthetica, 39:539543.

Marenco, R.A.; Gonçalves, J.F.C.; Vieira, G. $2001 \mathrm{~b}$. Leaf gas exchange and carbohydrates in tropical trees differing in successional status in two light environments in central Amazonia. Tree Physiol, 21:1311-1318.
Marshner, H. 1995. Mineral nutrition of higher plants. (2 ed). Academic Press, London. 889p.

Miyazawa, M.; Pavan, M.A.; Muraoka, T.; Carmo, C.A.F.S., Mello, W.J. 1999. Análises químicas de tecido vegetal. In: Silva, F.C. (Org). Manual de análises químicas de solos, plants e fertilizantes. Empressa Brasileira de Pesquisa Agropecuária. Brasilia, DF. p. 172-223.

Neves, E.J.M.; Reissmann, C.B.; Ferreira, C.A.; Bellote, A.F.J.; Dünisch, O. 1999. Nutritional status of Ceiba pentandra (L.) Gaertn. and Virola surinamensis (Rol.) Warb. growing on poor soils in the Brazilian Amazon region. Mitteilungen, 193:71-77.

Oberbauer, S.F.; Strain, B.R. 1984. Photosynthesis and successional status of Costa Rican rain forest trees. Photosyn. Res., 5:227-232.

Whitmore, T.C.; Wooi-Khoon, G. 1983. Growth analysis of the seedlings of balsa, Ochroma lagopus. New Phytol., 95:305 311 .

Zotz, G.; Winter, K. 1994. Photosynthesis of a tropical canopy tree, Ceiba pentandra, in a lowland forest in Panama. Tree Physiol., 14:1291-1301.

Submetido à publicação: 16/08/2001.

Aceito: 19/06/2002. 